\title{
Blackness and Urban Popular Sectors in Buenos Aires (1895-1916): The Case of Zenón Rolón and Chin-Yonk ${ }^{1}$
}

\section{Lea Geler}

Consejo Nacional de Investigaciones Científicas y Técnicas (CONICET), Argentina

Instituto de Historia Argentina y Americana "Dr. Emilio Ravignani”

(Universidad de Buenos Aires)

Geler, Lea. 2013. “Afrodescendencia y mundo urbano popular en Buenos Aires (1895-1916): el caso de Zenón Rolón y Chin Yonk.” In García Jordán, Pilar (ed.), La articulación del Estado en América Latina. Barcelona: PiUB, 207-226.

\section{Introduction}

Until quite recently, most Argentines vehemently maintained that the nation's Afrodescendant population-the descendants of enslaved African men and women-had "disappeared" due to a series of unfortunate events. ${ }^{2}$ For more than a century, this understanding made it possible to define the nation as white and European. But the apparent disappearance of Afro-Argentines was in fact part of complex social processes by which the Afrodescendant popula-

1. Translated by Paulina L. Alberto. I would especially like to thank María de Lourdes Ghidoli, who facilitated my access to the magazine Plus Ultra and other historical documents that made this essay possible. I would also like to thank Florencia Guzmán for her insightful comments on an earlier version of this text.

2. Traditional explanations include the end of the slave trade in the mid-nineteenth century; disproportionately high mortality rates in epidemics or because of the supposed use of black and mulatto battalions as cannon fodder over the course of multiple nineteenth-century wars (especially the Paraguayan War of 1865-1870); and, to a lesser extent, widespread racial mixture. On these explanations and their varying degrees of historical accuracy, see George Reid Andrews, The Afro-Argentines of Buenos Aires, 1800-1900 (Madison: University of Wisconsin Press, 1980). 
tion was actively rendered invisible. These processes of social erasure known to many academics and activists today as "invisibilization" took place principally through the erosion and suppression of non-white racial categories, resulting in a broad definition of whiteness that subsumed people of African or Indigenous descent and denied the existence or possibility of diversity within a nation constructed on the principle of homogeneity.

Toward the end of the nineteenth century, after decades of leading Argentine thinkers and politicians pronouncing the imminent demise of the colonialera Afrodescendant population, it finally came to fruition. Yet this occurred not through high death rates in wars or from diseases, as contemporary thinkers had postulated, but primarily through various mechanisms of concealmentabove all, the elimination of race-based categories in official censuses. ${ }^{3}$ As we might expect, people of African descent did not really disappear; they continued to live in the country, just as they do today, contending with narratives of disappearance that have been continually imposed upon them. ${ }^{4}$

During that same period, Buenos Aires-the Federal Capital of the Argentine Republic - was reshaped by the arrival of hundreds of thousands of European immigrants attracted by the Argentine state's pro-immigration policies. Among the city's many transformations in the context of mass immigration (and nativist reaction) was the emergence of a popular theater movement, for and by Argentines and focused on local themes, known as the género chico. ${ }^{5}$ This emerging popular genre-disdained by the nation's elites, for whom only "cultured" European plays were considered of acceptable quality-became a crucial fertile space of social interaction for an urban population in a state of constant flux and growth. ${ }^{6}$

This article focuses on the 1895 premiere of the play Chin-Yonk, ${ }^{7}$ whose

3. The substance of this disappearance had to do in large part with decisions not to count the Afrodescendant population in censuses and most other statistical instruments from the midnineteenth century onward. In this way, the Afro-Argentine presence went unrecorded in official figures that were understood, within the period's positivist framework, as a faithful reflection of reality. Andrews, Afro-Argentines.

4. Lea Geler, Andares negros, caminos blancos: Afroporteños, estado y Nación Argentina a fines del siglo XIX (Rosario: Prohistoria Ediciones/TEIAA, 2010).

5. The género chico, as theater historian Jorge Dubatti explains, was so called to distinguish it from the género grande or "cultured" theater, whose plays were longer and their production supposedly of higher quality. The género chico tended to be short comical plays with lively musical scores, like sainetes or zarzuelas. Jorge Dubatti, Cien años de teatro argentino. Desde 1910 a nuestros días (Buenos Aires: Biblos, 2012).

6. Adolfo Prieto, El discurso criollista en la formación de la Argentina moderna (Buenos Aires: Siglo XXI, 2006).

7. Chin-Yonk was a humorous play that referenced the famous police case that shook London in the late nineteenth century-the serial murders by Jack the Ripper-adapted to the local context via a real-life case in Buenos Aires: City police had found a body bearing the telltale signs of the Ripper's procedures in the upscale neighborhood of Recoleta. Chin-Yonk was the name given to the local Jack the Ripper character. The play was set in the Andes mountain range and 
score was composed by the famous Afro-Argentine musician Zenón Rolón. Rather than analyze the play itself, I will use contemporaneous and subsequent accounts of its début at the city's Teatro de la Comedia to analyze changes and continuities in racial categories, and in racialization more broadly, in a city increasingly constructed as white and European at the turn of the twentieth century. Significantly, while Chin-Yonk fell squarely within the low-brow género chico, its authors, Enrique García Velloso and Mauricio Nirenstein, were schoolmates at the Colegio Nacional (today, the Colegio Nacional de Buenos Aires) - then the most prestigious high school in the city, serving the children of Buenos Aires' intelligentsia and upper classes. ${ }^{8}$ These two teenagers set out to write and stage a play in the massive vibrant capital city and, remarkably, they succeeded. Indeed, García Velloso (1880-1938) went on to have a long and prolific career in theater, with more than one hundred plays to his name, and is now remembered as a foundational national playwright. ${ }^{9}$

Zenón Rolón (1856-1902), for his part, was an accomplished musician who in 1873 received a state-sponsored scholarship to study composition in Florence, Italy. Back in Buenos Aires, he performed at the prestigious Teatro Colón, among many other venues. When, in 1880, the government arranged for the restitution of the remains of independence hero José de San Martín from France to Buenos Aires, it was Rolón's funeral march that accompanied the official ceremonies. ${ }^{10}$ Rolón is perhaps best known for his symphonic march "Falucho," first played at the 1897 inauguration of the monument to that legendary Afro-Argentine soldier of the independence wars. In 1881 Rolón, along with his business partner Ezequiel Oca, opened a publishing house specializing in lithography and sheet music. ${ }^{11}$ The next year Rolón won second place in a musical competition held at the Continental Exposition in Buenos Aires-a feat in which the city's Afrodescendant community (of which Rolón was a prominent member) took great pride. ${ }^{12}$ In 1887 he was named professor took place entirely inside a train car. See Enrique García Velloso, Memorias de un hombre de teatro (Buenos Aires: EUDEBA, 1960 [1942]). This text is a reprint (with minor modifications) of Enrique García Velloso, “Cómo se estrenó mi primera obra," Plus Ultra, July 1916, n/p.

8. García Velloso was fifteen years old and Mauricio Nirenstein was seventeen.

9. He was the founder (in 1910) and director of the Asociación de Autores Dramáticos (today known as Argentores, a playwrights' mutual association), as well as the founder and president of the Casa del Teatro. So extensive was García Velloso's roster of authored plays and so far-reaching his work on behalf of the theatrical arts - in the roles of union activist, historian, teacher, journalist, playwright, and so forth—that Dubatti describes him as "ubiquitous." Dubatti, Cien años de teatro argentino, 67.

10. Marcos de Estrada, Argentinos de origen africano (Buenos Aires: EUDEBA), 147.

11. La Broma, 20 May 1881.

12. Geler, Andares negros, caminos blancos, 128-129. On that occasion, the Afro-Argentine newspaper La Broma announced: “Señor Don Zenón Rolón’s musical compositions earned him one of the first prizes at the Exposition. From our humble circle we congratulate one of the most gifted musicians of our national roster.” La Broma, 20 May 1881. 
of music at the schools of the National Council of Education [Consejo Nacional de Educación]. ${ }^{13}$

The pages that follow focus on representations of Zenón Rolón in various accounts of the 1895 début of García Velloso and Nirenstein's play. After sketching the image of Rolón that emerged in the press coverage of Chin-Yonk's début, we turn to García Velloso's subsequent narrative of those events. Since Chin-Yonk was his first play and his first début, García Velloso left behind multiple accounts of the event that together offer a vivid description of his memories of that night. One of these-perhaps the first-appeared in the magazine Plus Ultra (Buenos Aires) in 1916. Another appeared several decades later, in 1942, with the publication of his memoirs, Memorias de un hombre de teatro, in the chapter titled "My First Premiere." ${ }^{14}$ The chapter is virtually identical to the 1916 article in Plus Ultra, with a few paragraphs added toward the beginning of the text. It is worth noting that Memorias is a foundational text in history of Argentine theater and frequently used as a primary source. Together with José Podestás Medio siglo de farándula (1930), it is among the very few sources produced during the birth of the national theater movement by one of its protagonists-part of a subgenre that theater historian Jorge Dubatti calls "theatrical memoir." ${ }^{15}$ In other words, García Velloso's Memorias is a canonical text and a frequently consulted source within the established "archive" of theater history. ${ }^{16}$

I compare the press' contemporary coverage of the début with García Velloso's subsequent accounts to reveal shifting sensibilities about race and racial categories in turn-of-the-century Buenos Aires. Longstanding ideas about the city's popular sectors played an important role in these shifting conceptions of race. Specifically, an intricate amalgam of ideas about race and class gave rise, by the early twentieth century, to a new form of blackness or negritud-distinct from the blackness or negritud of African origin-in the white capital city: the blackness of the popular sectors, which I call "popular blackness" (negritud popular). This concept, albeit modified by a century of historical change, remains in widespread use in Buenos Aires today. As we will see, these shifts in racial sensibilities and the emergence of a new socio-racial formation in Argentine society emerge with special clarity in García Velloso's early twentiethcentury remembrances of his youthful collaboration with Afro-Argentine musician Zenón Rolón. It is to that story that we now turn.

13. Estrada, Argentinos de origen africano, 147.

14. First published as Enrique García Velloso, Memorias de un hombre de teatro (Buenos Aires: Guillermo Kraft, 1942). Here I use the EUDEBA edition of 1960, comprised of selections of the original.

15. Dubatti, Cien años de teatro argentino, 38.

16. Michel-Rolph Trouillot, Silencing the Past. Power and the Production of History (Boston: Beacon Press, 1995). 


\section{The 1895 Premiere}

The premiere of Chin-Yonk, which took place on November 30, 1895, garnered reviews in the theater pages of several of the city's newspapers. Those in $\mathrm{La}$ Nación (one of the city's leading dailies) and El Tiempo (an evening paper) were particularly extensive. Indeed, La Nación had announced the play to its readers the day before the opening: "Premiere at the [Teatro de la] Comedia: Tomorrow, Saturday, this theater will stage the début of a zarzuela [short musical comedy] titled Chin-Yonk, scripted by two young Argentines who attend the Colegio Nacional, and scored by the reputable maestro Zenón Rolón." ${ }^{17}$ The day of the début, La Nación ran an almost identical advertisement, with the addition of the actors' names. El Tiempo, for its part, similarly announced the play and noted that it was written by "two young Argentine students of the Colegio Nacional, with music by a distinguished maestro." ${ }^{18}$ Whereas neither paper named the playwrights, they both highlighted the fact that the score was composed by an accomplished and renowned composer. La Nación underscored Rolón's participation by publishing his full name.

In the days that followed the premiere, both newspapers carried reviews of the play. This is significant, since at the time newspapers did not necessarily review all plays that premiered in the city's theaters, only those that particularly captured the attention of journalists and critics. The critic for La Nación wrote of Chin-Yonk:

[Teatro de la] Comedia: Well. Now that the young and callow playwrights of the zarzuela Chin-Yonk, which premiered yesterday in that theater, have regaled their ears and their imaginations with much applause and curtain calls proffered by an affectionate and also rather callow public, let me, as someone who loves them no less than those who flattered them so thoroughly last night, offer an observation and a word of advice. The observation is that their play suffers-and not lightly-of diffuseness and of an excessive lethargy in the lead-up to the scenes of the final act [ ... ] So to spare them the many other observations that could be made of a little play such as this-a first work that naturally abounds in defects, due to [the authors'] lack of experience-let us move on to the word of advice. The authors of the script should not read too much into last night's applause, nor should they allow themselves to be beguiled by it. [They should] accept it, rather, as a fortuitous event that authorizes them to continue on the thorny path upon which they embarked last night-not in an even more carefree manner, but by redoubling their care and effort, by painstaking attention

17. “Teatros," La Nación, November 29, 1895.

18. "Los teatros," El Tiempo, November 30, 1895, $2^{\text {nd }}$ edition. 
to detail. Know that what was not demanded of you yesterday will be demanded another day. ${ }^{19}$

Judging from this account, the play was a success, reaping ample applause and praise-albeit unjustified, from the critic's perspective-and the playwrights received multiple curtain calls, a spontaneous affirmation of the play's positive reception.

The review in El Tiempo, published a day later, on December 2, sounded a similar note:

[Teatro de la] Comedia: On Saturday, the young authors of the little zarzuela "Chin Yonk," señores García Velloso and Nirenstein, had a good début. We say "good" because they have conceived their subject matter well, exhibiting intelligence, but what they lack-what they cannot yet possess because of their youth-is experience in the theater, something that can only be acquired through years of hard work. This is why the plot comes across as diffuse and plodding, the final scene alone offering any interest [...]. The theater was packed to the rafters and the public heartily applauded the playwrights, repeatedly calling them back onto the stage. Such applause should not lead the young authors of "Chin Yonk" to become complacent; they must continue to exert themselves, for they represent a great hope for our national theater. ${ }^{20}$

As in La Nación's review, the theater critic for El Tiempo describes a full house that offered enthusiastic encouragement and applause, even in the face of the many dramaturgical shortcomings - which this critic also omitted in the interest of brevity-stemming from the playwrights' youthful lack of experience. Both critics, finally, entreated the authors to correct such missteps in future productions.

Yet the theatrical reviews also commented on Rolón's musical score. $\mathrm{La}$ Nación opined:

As for the music that maestro Zenón Rolón has graciously agreed to compose for this script, we hope the playwrights will not be unduly offended if we say that [its quality] far exceeds what might be expected from such a light subject. Almost all his numbers are of great appeal, beginning with the elegant 'Prelude with canto interno', and display a commendable tendency to use criollo [local, national] motifs. ${ }^{21}$

19. “Teatros," La Nación, December 1, 1895.

20. "Los Teatros," El Tiempo, December 2, 1895, $3^{\text {rd }}$ edition.

21. “Teatros," La Nación, December 1, 1895. 
El Tiempo similarly noted:

Maestro Zenón Rolón appears to have composed the score with no regard for the script, to which his music is greatly superior. Señor Rolón's music is not only of high craftsmanship, but also very original, pleasing, and at times elegant, although it does not quite fit with a script that is, in essence, comical. $^{22}$

Given that mainstream newspapers in this period disdained the género chico and glorified any type of artistic production considered cultured, that is, of classical European origin, they were pleased by the music Rolón had composed, which fit that criterion. Rolón did, in fact, follow the classical European style in his compositions, despite the review's suggestion that he managed to include other, criollo rhythms, if only through minor motifs [aires]. The only criticism reviewers offered of Rolón was that his music was simply too good for a play with many weaknesses and so little to recommend it. La Nación similarly framed Rolón's collaboration as more of a favor to the young playwrights than a serious professional engagement. But most importantly for the discussion here, none of these articles so much as mentions the fact that Rolón was a man of African descent. ${ }^{23}$ We now turn to García Velloso's account of those same events twenty years later, when he had become an acclaimed playwright.

\section{The Premiere According to García Velloso (1916)}

In his article "The Premiere of My First Play" [Cómo se estrenó mi primera obra], published in the magazine Plus Ultra in 1916, García Velloso explained that much of his audience for Chin-Yonk was composed of friends and classmates from the Colegio Nacional. This, as mentioned earlier, was a school that trained the children of the lettered elite, the social class from which García Velloso himself hailed. As he recalled it,

22. "Los Teatros," El Tiempo, December 2, 1895, $3^{\text {rd }}$ edition.

23. This was unfailingly the case every time mainstream newspapers mentioned Afrodescendants by name in this period, as in La Nación's first-page coverage of the state funerals for Colonel José María Morales in 1894. See Lea Geler, “'Hijos de la patria’: tensiones y pasiones de la inclusión en la Nación Argentina entre los afroporteños a fines del siglo XIX," Memoria Americana, no. 20:2 (2012): 273-294. This was a strategy of erasure based on liberal principles: i.e., that race or color should not matter because all men were capable of progress, and so race and color went purposely unmentioned. But this strategy also veiled the very powerful forces working toward Europeanness and whitening, which would result in the implicit equivalence of Argentineness with white-Europeanness. To progress was, by definition, to become more European or white, both characteristics understood to be the most desirable options. 
Never before had any playwright from Buenos Aires débuted a play before an audience as dangerous as the one that congregated that unforgettable night at the Comedia. Suffice it to say that all the students of the Colegio, all of them, filled the theater; I need not spell out the kinds of perils to which we exposed ourselves ... ${ }^{24}$

This comment alludes partly to the fact that, in those days, it was common practice for audiences in popular theater to comment openly on the plays they watched. Spectators passed judgment on a play on the spot and instantly, by whistling, hissing, or smashing the seats if they judged it negatively, or clapping and acclaiming the playwrights, if the verdict were positive. This sort of interaction could also include conversations or dialogue - of varying tenors - with the actors on stage, who oftentimes responded directly and spontaneously to the audience. ${ }^{25}$ Popular theater thus became a space for contact, interaction, and dialogue in which porteños (residents of the city of Buenos Aires) of different social backgrounds forged new tastes, aesthetics, styles, and opinions-a particularly important function in a rapidly changing capital city. Yet the evening as García Velloso recalled it followed a different path than the one prescribed by the rituals of the city's popular theater.

García Velloso continues the story of that famous evening:

At ten in the evening not a single woman was to be seen in the theater. [ ... ] Only one balcony remained empty. [ . . . ] For whom was it being reserved? . . . Then, just minutes before [the start of the show], Ebe, Cloe, the fat negra, a negro with eyeglasses and four more morenas made their solemn entrance-these latter were dressed to the nines, overflowing with red feathers, showy corsages, chains, and reliquaries . .."26

"Ebe, Cloe, a fat negra, a negro with eyeglasses, and four more morenas" were members of Rolón's family, all of them people of African descent. That they were recognized as such by other porteños is evident in García Velloso's choice of language, since the terms negro and moreno referred clearly to dark-skinned individuals of known African descent. The author's extremely sarcastic tone was intended to make fun of the supposed-and supposedly obvious-gaudiness and lack of refinement displayed by these individuals in their choice of clothing and adornment. This, together with their skin color-which in those years was becoming an ever more indelible sign of social and biological inferioritycast these persons as iconic embodiments of the popular grotesque. In Mikhail

24. García Velloso, Memorias, 86. Emphasis in the original.

25. Osvaldo Pellettieri, El sainete y el grotesco criollo: del autor al actor (Buenos Aires: Galerna, 2008).

26. García Velloso, Memorias, 87. 
Bakhtin's famous definition, the popular grotesque is characterized by exaggeration, pomposity, the centrality of the body and its functions (the sexual, the scatological), and by ambiguity (appearing to be two things at once or presenting oneself other than how one truly is) ${ }^{27}$ But whereas in the carnivalesque celebrations of medieval Europe (the subject of Bakhtin's analysis) that form of humor targeted the entire population and eliminated or upended social hierarchies, in the context of late nineteenth-century Buenos Aires the effect was the reverse: the popular grotesque delimited social hierarchies according to the taste of the city's hegemonic sectors. Far from creating a comic effect that would be appreciated across different groups, the trope of the popular grotesque turned one group into the object of another's mockery and scorn. And the well-to-do young men of the Colegio Nacional would have latched onto that derisive trope immediately and driven its humor to the farthest extremes.

And so García Velloso's account pushes on:

I, who was peeking through a hole in the curtain, felt almost as if the earth was cracking open beneath my feet ... "Something's afoot," I told Nirenstein ... [ . . ] Just then, the audience exploded in a formidable standing ovation for the occupants of the [last empty] balcony [ ... ]. I don't know what happened next ... I only recall that Rolón seemed to vibrate with excitement, and that at each round of applause-clearly meant in mockeryhe wanted to drag us on stage to take a bow ... I need not tell you that had we gone onstage in those circumstances ... they would have killed us ... The show ended and we had no alternative but to face up to the obligation to appear on stage ... Rolón strode toward the footlights and waved his wide gray hat like a victory banner ... [ . . . "It was a resounding success!" Rolón shouted. [ . . . ] I was close to believing it myself and I headed over to the administration to request a balcony so that my own family could witness that wonder of a play. [The administrator denied my request and said], "Some premiere! The carpenters and upholsterers will be busy for days. [The audience] has left the seats in a miserable condition ..." "You mean damage was done?" [García Velloso asked] [ ... ] "Was damage done? They even lifted tiles from the mosaic!” ... Nirenstein and I, without saying a word, our heads down, and saddened, set out walking along Artes street [... when] out from among the trees there came an admirable baritone voice, piercing the silence of that discouraging night: "Goodbye, victors! Goodbye, magnificent poets!" ... And the whole negrada [derogatory slang term for a group of black people] applauded us boisterously. ${ }^{28}$

27. Mikhail Bakhtin, Rabelais and his World (Bloomington and Indianapolis: Indiana University Press, 2009 [1965]).

28. García Velloso, Memorias, 87-88. Emphasis mine. 
According to García Velloso, then, the premiere had been a spectacular failure. Yet he makes no mention of any kind of dramaturgical misstep on his or Nirenstein's part. Instead, his account of that moment, focused on Rolón, is steeped in an explicit, unapologetic racism intended to incite laughter in readers and establish their complicity with the well-to-do young men of the audience and with García Velloso himself. The association of the "negrada" - a deeply offensive word-with trees, and by extension with monkeys (the animal with which Africans and visibly black Afrodescendants had been compared for decades, and which cast them as unthinking animals or legal minors-in other words, a chain of associations connecting directly to slavery and the colonial past), was also clearly meant to ridicule and diminish Rolón. The childlike caricature of Rolón, supposedly unable to understand the mockery behind the thunderous applause, extends as well to his ingenuousness and his entire group of relatives. These characterizations placed Rolón and the other Afrodescendants in a clearly subaltern position, casting them as innocent and manipulable. Notably, García Velloso makes no mention whatsoever of the audience's response to the play itself or to the music Rolón composed. Instead, he focuses on theatergoers' taunting of Rolón and his companions, for which there was seemingly no other reason than their mere presence in the theater. In other words, Rolón and his family were mocked simply for being in the wrong place at the wrong time.

Significantly, García Velloso once and again refers to Rolón as "black":

... a sublime negro [ . . . ] He was a magnificent specimen, a truly beautiful type, a statue carved in ebony. With his baritone voice-joyful and boisterous-he greeted me, [. . . drawing] from the depths of his chest deep baritone notes I can still hear [ . . ] launching into the air a peal of happy laughter, which revealed a set of teeth that flashed in his mouth with the whiteness of lime. ${ }^{29}$

This description of Rolón's bodily presence, which so greatly impressed García Velloso in this account, echoed widespread stereotypes of the hypersexualized black male body, one whose masculinity overflowed limits prescribed by contemporaneous gender norms. The focus on Rolón's corporeality also mobilized the animalization or objectification of Afrodescendants implicit in the stereotypes, making it possible to present Rolón as a "specimen" or "type" assumed to be valid and recognizable by readers. The depiction of a black man bursting into peals of laughter, with his mouth wide open and showing his teeth, is also a typical racial trope evident even today in commercials and advertisements: a happiness that reveals these individuals to be gullible and dumb (since what possible reason, the thinking goes, could black people have to be happy?). This

29. García Velloso, Memorias, 83. Emphasis mine. 
trope firmly associates black people with the body's natural and excessive reactions, and casts them as vectors of happiness, especially through dance and music. Further along in his text, García Velloso persists in this line: "There was Rolón looking like a dandy, with his navy blue suit and his Moorish beard, which contrasted with that gray hat of his, with its enormous brim ..." ${ }^{30}$ The emphasis on Rolón's appearance as a dandy was meant as an ironic commentary on the inherent impossibility that a black bestialized body like the one García Velloso had described only a few lines earlier could actually be a dandy. It also alluded, less directly, to a set of internal differentiations and attempts at social mobility then taking place across the city's popular sectors - and certainly within the Afroporteño community-which were often encoded in sartorial choices. ${ }^{31}$

Clearly, the description of the premiere by the journalists who attended it in 1895 had nearly nothing in common-regarding the events of the evening or perceptions of Rolón-with the account in García Velloso's 1916 memoirs. This offers a series of interesting questions for analysis. But before hazarding an interpretation of the glaring slippage between these two sets of texts, we must first sketch the basic historical context in which they were produced.

\section{The Bigger Picture}

Broadly speaking, the republican and liberal ideas that guided the construction of the Argentine nation in the second half of the nineteenth century drew from Enlightenment principles that took root in the Río de la Plata following the success of the May Revolution of 1810, when creole elites declared self-government. These principles proclaimed the equality of all men (but not women) and the possibility that everyone could achieve progress, which in turn brought prestige and respectability. Progress was, of course, understood in terms of European modernity and whiteness, as civilization locked in perpetual battle with autochthonous barbarism. With the passing of years and the entrenchment of capitalism, progress became increasingly correlated with the attainment of economic wellbeing. The nation's elites and intellectuals envisioned a range of paths by which those not fortunate enough to belong in their ranks could achieve progress: through salaried work, education, good manners, care in dress, and the responsible exercise of military and political citizenship, among others. But because this vision of progress understood social

30. García Velloso, Memorias, 84. Emphasis in original.

31. Geler, Andares negros, caminos blancos; Lea Geler, "¿Qué sería de la sociedad sin moda?' Afrodescendientes de Buenos Aires, inclusión nacional y moda a fines del siglo XIX," in Histórias do pós-abolição no mundo atlântico, Vol. III, ed. Carolina Vianna Dantas, Beatriz Loner, Hebe Mattos, Karl Monsma and Martha Abreu (Niterói, Rio de Janeiro: EDUFF), 33-52. 
status as an outcome of merit and worth to which anyone could theoretically aspire, the onus to achieve it increasingly fell upon the shoulders of individuals. By this logic, those who found themselves unable to progress or to "regenerate" were held responsible for their own failure and made to bear the full brunt of society's reprimands. ${ }^{32}$ The ultimate goal, civilization, was thus represented as both desirable and achievable. This process reached its apex in 1880, the year in which Julio A. Roca assumed the presidency and began definitively to consolidate the national state through a range of policies aimed at improving Argentina's population-education laws, immigration laws, vagrancy laws, and military service, among others.

That ideal version of the Argentine nation was designed, discussed, and pursued by members of the local elite who championed liberal ideas and saw themselves as the natural leaders of a people who desperately needed them. To them, public debate was an inextricable part of the game of politics and of the national enterprise, and so they thoroughly expressed their ideas in newspapers, essays, and speeches. Indeed, one of the most prominent figures in this arena was Bartolomé Mitre, who, in addition to becoming president of the Republic in 1862, commanded a series of revolutions and uprisings (including one in 1890), and pioneered the writing of Argentine history (Mitre is considered one of the founders of Argentine historiography). He also founded the leading daily newspaper La Nación. From his position as a journalist, he continued to wield great influence in Argentine public life as late as 1895, over a period of deep social, political, and ideological transformations.

Thus, the supposed disappearance of the Afrodescendant population began to take shape as a result of processes underway from the middle of the nineteenth century. That disappearance, as explained earlier, must be understood as part of the processes of whitening and modernization, whose pressures were only exacerbated by the arrival of hundreds of thousands of European immigrants. ${ }^{33}$ Yet there was one more component to this social erasure: the complex processes by which blackness and the popular world came to be conflated. Afrodescendants in Buenos Aires had long occupied a central place in the urban popular world as workers, military men, cultural agents, and voters and electoral operatives. ${ }^{34}$ Indeed, over the second half of the nineteenth

32. Mónica Quijada, Carmen Bernand, and Arnd Schneider, Homogeneidad y nación: con un estudio de caso: Argentina, siglos XIX y XX (Madrid: Consejo Superior de Investigaciones Científicas, Centro de Humanidades, Instituto de Historia, 2000); Verena Stolcke, Racismo y sexualidad en la Cuba colonial (Madrid: Alianza, 1992).

33. Geler, Andares negros, caminos blancos.

34. Beginning in the second half of the nineteenth century, Afro-Argentine men played a crucial role as an electoral base and as agents of voter mobilization for candidates of all parties. This placed them in a position to negotiate with politicians of different levels (for specific policies or for government jobs, for example) and to attain a certain degree of recognition. Geler, Andares negros, caminos blancos. 
century, terms like "negros," "gente de clase" [people of the class of color], or "gente de color" [people of color] were frequently deployed as metonyms for popular sectors more broadly. Blackness, in other words, came to name and stand in for the popular world as a whole. ${ }^{35}$

In general, the "popular blackness" of the 1880s and 1890s-at the height of European immigration-referred to characteristics considered criollo or authentically local. Examples of this include viveza (natural wiles or street smarts), the milonga (a form of music and dance with Afro-Argentine influences that took root among lower classes and in the city's marginal neighborhoods and was associated with a rough lifestyle), and the prostitutes and compadritos (street toughs) associated with those marginal worlds. Indeed, so close was the association between compadritos and negros, and between prostitutes and pardas [women of mixed African and European ancestry], that the terms were often used interchangeably. The blackness of the popular world in these years also referred to violent, excessive, and bombastic behaviors and gestures, as well as sentiments like melancholy and seductiveness. These elements almost all chime with Bakhtin's notion of the grotesque, in which ambiguity and excess are hallmarks: excess in dress, excess in forms of behavior, excess in corporeality and sexuality. But in these years blackness also connoted the possibility of education (in terms both of formal schooling and the acquisition of polite manners), of social mobility, and the regeneration of a population long imagined as submissive and loyal servants. The obverse of this view was that the black popular sectors were also easily fooled and manipulated by flattering tyrants, like Governor Juan Manuel de Rosas, whom liberals had despised for his courting of Afrodescendants and other plebeians in the early nineteenth century. In these forms, blackness was far from reducible to skin color. Moreover, by the end of the nineteenth century, the figure of the negro also occupied a symbolic space in contexts ritually central to the popular world, like Carnival (which by then had entered its decline), and popular theater, which was on the rise. ${ }^{36}$

But by the 1880s this historical context began to change. As historians have amply demonstrated, 1880 marked a turning point in Argentine history that included deep political, social, cultural, and economic changes along with a shift in ruling elites' perceptions of the popular classes, and of Afrodescendants in particular. ${ }^{37}$ According to historian José Luis Romero, the

35. Geler, Andares negros, caminos blancos.

36. Lea Geler, "¿Quién no ha sido negro en su vida? Performances de negritud en el carnaval porteño de fin-de-siglo (XIX-XX)," in El Estado en América Latina. Recursos e imaginarios, siglos XIX-XXI, ed. Pilar García Jordán (Barcelona: PiEUB/TEIAA, 2011), 183-211; Lea Geler, "Un personaje para la (blanca) nación argentina. El negro Benito, teatro y mundo urbano popular porteño a fines del siglo XIX," Boletín americanista, no. 63 (January 1, 2011): 77-99.

37. See, for example, Ricardo Cicerchia, Historia de la vida privada en la Argentina. Tomo II: Desde la Constitución de 1853 hasta la crisis de 1930 (Buenos Aires: Troquel, 2001). 
process of nation-state consolidation that began in 1880, together with massive European immigration and Argentina's rapid incorporation into world capitalism as an exporter of agricultural goods, gave rise to new demands by workers and led ruling elites to close in upon themselves to guard their sources of wealth. That wealth was, in fact, becoming ever greater: after 1880, when the state concluded most of its campaigns of subjection and displacement against the indigenous populations of Patagonia, the ruling elite was left with vast tracts of land and free access to the goods and wealth they produced. The nominally liberal elite thus became an oligarchy fully divorced from what it considered the popular masses.

As Argentine liberalism took on conservative and even repressive overtones, leading thinkers and politicians embraced scientific ideas about race then circulating across the Atlantic world. Argentine elites came to understand races as biologically determined to be superior or inferior, and to see in racial mixture the risk of degeneration. Not surprisingly, one of the most pressing debates among Argentine ruling classes in those years centered on protecting the "national race" against any possibility of degeneration. ${ }^{38}$ Elites saw their anxieties about degeneration confirmed by "positive facts" like criminality or madness, and their interpretive framework came to constitute what historian Ricardo Salvatore calls a "class outlook" (despite the fact that the ideas that informed it were often in tension with one another). ${ }^{39}$ In the words of another leading Argentine historian, Oscar Terán, that framework was “. . . a world of ideas and beliefs that inhabited the minds of a group of cultural agents at the very top of the porteño social-intellectual pyramid." 40 This social class kept itself in power in a quasi-hereditary fashion, closing itself off and distancing itself from a civil society that grew not only in numbers but in demands, and which increasingly made itself heard through any and all means within its reachattacks, revolution, strikes, and so forth. This only hardened the oligarchy's sense of besiegement and stoked its disdain and fear of everything beyond its ranks, which in turn gave rise to feelings of paranoia. ${ }^{41}$

Thus, elites met the rise in civil society's mobilizations and demands with repressive efforts to contain and control the so-called social question. Ruling

38. Dora Barrancos, "La construcción del otro asimétrico: mitos científicos entre los siglos XIX y XX," Revista Argentina de Sociología, 2, no. 2 (2004): 7-26; Eduardo A. Zimmermann, "Racial Ideas and Social Reform: Argentina, 1890-1916," The Hispanic American Historical Review 72, no. 1 (1992): 23-46.

39. Ricardo Salvatore, "Criminología positivista, reforma de prisiones y la cuestión social/ obrera en Argentina," in La cuestión social en Argentina. 1870-1943, ed. Juan Suriano (Buenos Aires: La Colmena, 2004), 128.

40. Oscar Terán, Vida intelectual en el Buenos Aires fin-de-siglo (1880-1910) (Buenos Aires: FCE, 2000), 9.

41. Gabriela Nouzeilles, Ficciones somáticas. Naturalismo, nacionalismo y políticas médicas del cuerpo (Argentina 1880-1910) (Rosario: Beatriz Viterbo, 2000). 
sectors disciplined society through a range of scientific and medical methods but also through newly restrictive laws such as the 1902 Law of Residence, aimed at controlling growing popular movements (the opposition Radical party, syndicalists, anarchists, or socialists) by deporting without trial any immigrants deemed suspicious. ${ }^{42}$

Nevertheless, pressures from civil society, together with the limited liberal policies that managed to emerge in such a conservative atmosphere, led to the reform of the electoral system in 1912, with the passage of a law instating the secret ballot and obligatory universal male suffrage. ${ }^{43}$ This electoral reform resulted in an upset in the April 1916 presidential elections, when Hipólito Yrigoyen, an outsider to the world of the oligarchy, and his upstart Radical Party (Unión Cívica Radical) won by a landslide. When Yrigoyen assumed the presidency in October of that year, it marked a new chapter in national history. The masses' rise to formal power occurred at a time when Argentine elites sought fervently to project to the world an image of their nation, and especially their capital city, as modern and European. Buenos Aires was promoted as the "Paris of Latin America," and Argentines understood themselves to be a population "descended from boats" - just not those that had sailed from Africa.

\section{Changing Sensibilities}

The deep transformations at the turn of the twentieth century and the stark incongruence between García Velloso's account (1916) and the contemporaneous critical reviews of his play (1895) point to changed sensibilities among elites toward the city's popular world. It seems likely, moreover, that this shift was underway as early as 1895, albeit not yet as fully formed as García Velloso's later testimony portrays it. Further support for this hypothesis comes from the clear generational difference between, on one hand, the playwrights and members of the audience (all students at the Colegio Nacional at the time of the 1895 premiere) and, on the other, the critics and composer (who belonged to an earlier generation).

Literary critic Raymond Williams coined the phrase "structures of feeling" to refer to "meanings and values as they are actively lived and felt, and the relations between these and formal or systematic beliefs [which] are in prac-

42. The oligarchy tackled the social question through ". . . an interpretive grid that allowed them to displace these [social] 'problems' onto new conceptual and intellectual terraincriminality, criminological laboratories, prisons-where those issues could be examined in relation to one another, classified, and understood." Salvatore, "Criminología positivista, reforma de prisiones y la cuestión social/obrera en Argentina," 128.

43. On the conservativism of the turn-of-the-century republic, see Natalio Botana and Ezequiel Gallo, De la República posible a la República verdadera (1880-1910) (Buenos Aires: Ariel, 1997). 
tice variable." Williams is concerned with the "specifically affective elements of consciousness and relationships: not feeling against thought but thought as felt and feeling as thought: practical consciousness of a present kind, in a living and inter-relating continuity." He defines these elements part of a "structure': as a set, with specific internal relations, at once interlocking and in tension," for structures of feeling are in a state of constant flux. Even as new ones emerge, Williams argues, they "are often more recognizable at a later stage, when they have been [...] formalized, classified, and in many cases built into institutions and formations." ${ }^{44}$ I argue that the contemporaneous theatrical reviews of ChinYonk and García Velloso's later account offer a particularly clear example of changes underway in the structures of feeling among elite porteños with respect to blackness and the popular world-without, of course, forgetting that these sensibilities are never fully coherent or homogeneous, but must be understood, rather, as constantly working to manage their own internal contradictions.

In this sense, it is possible to imagine that the sensibilities evinced in the newspaper reviews from 1895 responded to patterns that had taken shape in earlier decades, during the process of nation-building and state consolidation. These sensibilities imagined an enlightened liberal aristocracy as the natural leaders of a people they viewed as largely unfit but nonetheless capable of progress. And Rolón represented a successful example of precisely this ideology, on which the state had staked its resources and policies - the regeneration of its population through the broad extension of citizenship as well as through education, labor discipline, or racial mixing (mestizaje) with immigrants who would whiten and "improve" the population. This latter was, after all, the reason behind elites' call for European immigrants, who would help locals (considered indolent, uncultured, primitive, and so forth) pass, in cultural and biological terms, into modernity. It should come as no surprise, then, that newspapers like La Nación - which had been founded by one of the forefathers of the newly consolidated state-celebrated Rolón as the epitome of the kind of achievable progress they imagined for all members of the Argentine people. It is worth recalling, too, that Rolón had received state support in the form of a scholarship to study music in Europe.

The newspapers' positive response to Rolón's score was not an isolated event. On many other occasions, journalists had publicly praised his music, even in the context of popular theater. One of these was the 1899 premiere of another play for which Rolón had composed the score. La Nación wrote a favorable review of the music and later published a separate article in response to the fact that, after several shows, some of the maestro's music had been abridged or cut from the play altogether:

44. Raymond Williams, Marxism and Literature (Oxford: Oxford University Press, 1977), 132. 
The theatergoers who attended, for the first time last night, [ ... ] the zarzuela 'The Two Veterans' should not consider themselves well informed of the music that makes up said play, for to the cuts that were initially made to some of the [musical] numbers, last night was added the suppression of entire numbers altogether. [ ... ] The suppression of the chorus can be explained-if not justified-by the challenge that the correct execution of [that number] no doubt posed to singers as untalented as the ones in this and other theaters of the género chico. [ ... ] [We condemn] this suppression above all when it affects scores so pleasant and worthy of being heard as the ones written by maestro Rolón for this play. The music [ . . ] is far superior to that of most of those zarzuelas that for some time now have reached us accompanied by great fanfares of success, and which are announced locally in enormous bold letters. ${ }^{45}$

This review once again makes clear the centrality, from the critic's perspective, of the tension between high and popular culture, the dilemma of using European-style music-for which specific vocal training was required-versus music that included criollo melodies and rhythms. In this framework, Rolón was once again held up as an example of quality music and a level of culture that could be achieved through training and education. From the perspective of journalists in the bourgeois press, this was something that individuals who participated in the popular género chico (at the time, mostly European artists) failed to achieve or rejected altogether. By contrast, the figure of Rolón deserved praise and acknowledgment, for he had achieved something to be expected of, but rarely attained by, members of the popular sectors.

In fact, the image of Rolón that has endured-he is among the few nineteenth-century Afrodescendants whose likeness was preserved via photography-is exactly that of a modern gentleman of the day, a dandy, distant from anything that might be considered vulgar or primitive. ${ }^{46}$ By 1899 , on the occasion of a different theatrical premiere, the magazine Caras y Caretas published a closeup from Rolón's portrait, explaining in the text: "[The] music has been composed by the well-known Argentine maestro, Mr. Zenón Rolón." ${ }^{37}$

As we can see, there was nothing demeaning about Rolón's likeness; it could easily be shown in the bourgeois press, for his image fit with the ideologies of progress and modernity that dominant sectors considered appropriate for the masses. But however much individuals from the popular sectors might distinguish themselves, local elites closed off their access to the most privileged spaces of high culture and political decision-making. ${ }^{48}$ Because (ironically), the

45. "Teatros y conciertos," La Nación, January 21, 1899.

46. Geler, "¿Qué sería de la sociedad sin moda?"'

47. "Éxitos teatrales," Caras y Caretas, January 28, 1899.

48. Geler, Andares negros, caminos blancos. 


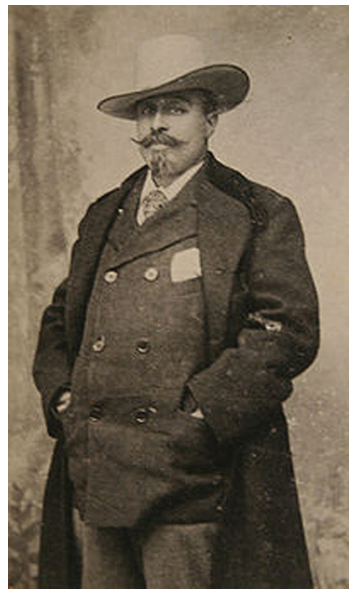

Image 1: Zenón Rolón. Archivo General de la Nación (from Andrews, AfroArgentines)

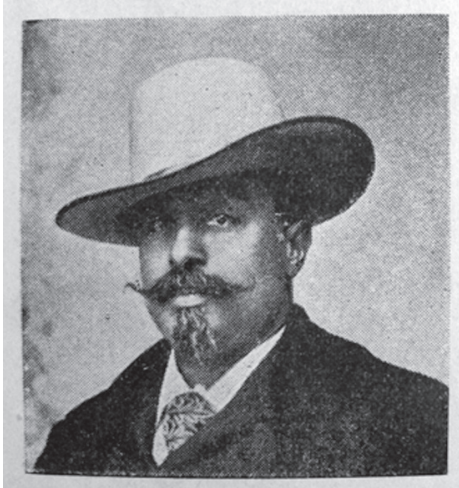

Image 2: Caras y Caretas, January 28, 1899

idea was that the mass should modernize itself-not that it should attain the status or social position of the dominant classes (or worse, displace them). So, on one hand, Rolón's image as a dandy successfully distanced him from other images of the masses then taking shape in the city: the compadrito, the milonga and the tango, the arrabales or slums, everything criollo. These icons of the urban underworld increasingly became synonymous with visibly black men, so that at the turn of the century to say "compadrito" was the same as to say "negro." ${ }^{49}$ But on the other hand, Rolón's appearance as a dandy came close, in the eyes of elites, to the disdained figure of the simulator-someone who imitated his "betters" or who tried to pass himself off as something he was not. Elite fears of simulation in this period reveal deep anxieties about aspirations

49. Geler, Andares negros, caminos blancos, 108. 


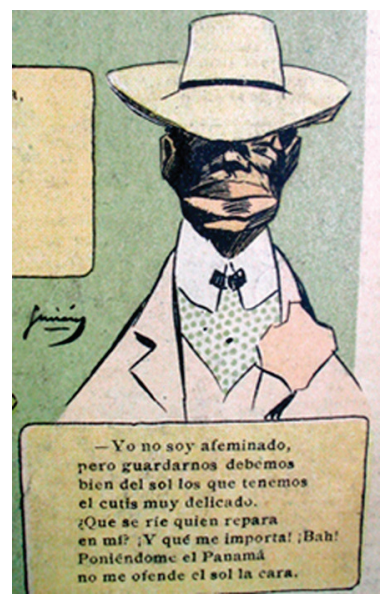

Image 3. Caras y Caretas, January 24, 1903

for social mobility among the popular sectors who were becoming ever more assertive and organized. It comes as no surprise then, that just a few years after publishing Rolón's portrait, Caras y Caretas would also publish racist and demeaning caricatures of black men that traded in worn stereotypes of the grotesque and the subculture of the compadritos, and which portrayed black men as putting on airs by dressing as dandies.

Indeed, the juxtaposition of contradictory representations in the same magazine illustrates the many ways porteños understood and related to the popular world, to race, to the question of national identity, and to the increased rigidity of social class. This was a particularly pressing set of issues when men of the popular sectors (pueblo) - as one distinguished member of the political elite called Rolón in $1899^{50}$-were gaining access to a modicum of social mobility thanks to their devotion to the shared values of progress. Even as they largely failed to have an impact in the world of political, social, or economic decision-making, their determined attempts to do so further stoked elites' suspicions and paranoia.

It was in July of 1916-just after the Yrigoyen presidential election that resulted in the masses' rise to political power and dealt a blow to the oligarchy-

50. In his account of Rolón's life, the Afroporteño writer Jorge Miguel Ford recalled that Marcos Avellaneda (at the time, president of the Chamber of Deputies) had congratulated Rolón on his creation of a social club: "I must congratulate you; that is, I must congratulate myself, señor Rolón, because this feat ( . . ) furnishes me with eloquent proof of the high degree of culture of my people [pueblo]." Jorge Miguel Ford, Beneméritos de mi estirpe. Esbozos sociales (La Plata: Tipografía de la Escuela de Artes y Oficios, 1899), 98. Through these words, we can glimpse how from the perspective of the porteño aristocracy, Afroporteños, even when they participated in the cultured arts, never ceased to be part of the pueblo-a group of citizens with which these aristocrats claimed a shared national identity, yet for whom they saw themselves as natural leaders. Through their intervention, the pueblo or masses could be regenerated or, more accurately, led toward regeneration. 
that García Velloso published his account of the Chin-Yonk premiere. His account did not appear in just any publication. Rather, it ran in the magazine Plus Ultra, a monthly supplement of the renowned Caras y Caretas for which García Velloso himself sometimes wrote. Plus Ultra had begun publication that same year; it was a high-quality production aimed at a particularly refined subset of Caras y Caretas' broad readership: “. . . the monthly enjoyment of a satinpapered magazine with a Latin title became the privilege of [residents of the aristocratic] Barrio Norte. With subjects ranging from carnivalesque insinuations to the Spanish royal insignia, [the magazine] conferred a kind of distinction that was understood as lineage." ${ }^{11}$ In other words, Plus Ultra offered a variety of news and notes in tune with a very specific lifestyle and aesthetic; it was a supplement aimed at a class that found itself increasingly displaced from politics and public life. In 1916 Plus Ultra presented itself as the refuge of an oligarchy that felt dispossessed of its right to govern the country at its own convenience.

According to sociologists Michael Pollak and Nathalie Heinich, “. . . every testimony is also, above all, anchored in the social conditions that make it understandable, conditions which change over time and vary from one country to the next." 52 In this sense, we must reinterpret García Velloso's memory of the event and contextualize it within its own moment, a moment when the dominant class to which the playwright belonged felt particularly besieged. García Velloso's emphasis on Rolón's appearance and on the mockery he and his family were subjected to drew attention away from the premiere itself and directed it to another problem. The negrada to which García Velloso refers was a logical extension of the metonymic processes by which the popular world was being supplanted by the idea of blackness [negritud]. For, as his photograph attests, Rolón's dress and stance stood in stark contrast to the irony and disdain with which García Velloso described them. We might then intuit that, in García Velloso's account, the term negrada referred to a group of grotesque imitators of an aristocratic class to which these men and women wished to belong or wished to supplant. They drew his scorn not just because of their clothing, manners, or color, but because they were invading a space - the gathering place of the white young aristocrats of Buenos Aires - that did not belong to them, just as the popular sectors were invading the Casa Rosada (the executive mansion and office of the president) and the presidential seat.

Therefore, while the reviewers at La Nación and El Tiempo narrated a ritualized experience of performance (along the lines of what is commonly de-

51. David Viñas, “Una revista VIP”, Página/12, March 14, 2004, Radar Libros section. Available at http://www.pagina12.com.ar/diario/suplementos/libros/10-978-2004-03-14.html (accessed October 2012).

52. Michael Pollak and Nathalie Heinich, "El testimonio," in Michael Pollak, ed., Memoria, olvido, silencio (Buenos Aires: Al Margen: 2006 [1986]), 56. 
scribed for late nineteenth-century popular theater), ${ }^{53}$ what García Velloso related was a theatrical experience connected exclusively to the social spaces of the oligarchy. According to journalists who, from the perspective of the late nineteenth-century cultural elite, dismissed fans of popular theater as ignorant, spectators from 1895 watched the play and applauded it, "without truly understanding" that it was atrocious. Yet the spectators García Velloso remembered in 1916 did not even watch the play, they did not meld into a communitas with the characters and the plot: rather, they watched (and mocked) Rolón and his family, the negrada that had invaded a privileged space.

Michel Foucault explains that "we live inside a set of relations that delineates sites which are irreducible to one another and absolutely not superimposable on one another." ${ }^{54}$ Precisely, then, in García Velloso's account of the premiere, Rolón and his family-as emblems of blackness and the popular world-were in the wrong place at the wrong time, and as such became the target of derision. A momentary heterotopia resulted, an other-space created by the juxtaposition of mutually irreducible and incompatible emplacements. ${ }^{55}$ The theater, as reimagined by García Velloso at the time of his account, was a space of the oligarchy, where the preservation of manners and ideas was corralled and under siege, giving rise to the heterochrony that accompanies all heterotopias. ${ }^{56}$

The idea of the masses as the negrada-which would become key to deriding the mobilization of multiracial popular sectors later in the twentieth century - was thus already emerging, although still embodied primarily by Afrodescendants. The masses had long been considered synonymous with blackness because of Afrodescendants' protagonism in the popular world, yet as we have seen, elites had considered negros capable of progress. But in 1916, as García Velloso wrote his memoir, the masses had been tarnished both by early twentieth-century conceptions of degeneration and inferiority (sustained by scientific racism) and by a new political conjuncture in which popular sectors began to rise up and make demands, leading to reactionary portrayals of the masses as hopelessly infantile and unable to govern. By 1916, elite Argentines no longer saw any possibilities of progress for these negros. Instead, they looked toward the positivist sciences that reigned supreme in the first decades of the twentieth century-hygiene, eugenics, criminology, psychiatry- to control and punish them.

As Foucault describes them, some heterotopias appear open and easy to

53. Silvia Pellarolo, Sainete criollo. Democracia/Representación. El caso de Nemesio Trejo (Buenos Aires: Corregidor, 1997).

54. Michel Foucault, "Of Other Spaces: Utopias and Heterotopias," Architecture /Mouvement/ Continuité October (1984 [1967]), 3.

55. Foucault, "Of Other Spaces."

56. Foucault, "Of Other Spaces." 
enter, when in fact by simply entering one is immediately excluded. Similarly, the way in which Rolón and his family were singled out for the mere act of entering a preserve of the oligarchy confirmed the exclusion inherent in that space. At the same time, the reaction Rolón's presence caused bears a strong resemblance to the idea-persisting until today-of a popular or negro invasion of spaces considered civilized/European/white. The trope of invasion would be mobilized throughout the twentieth century by white elites and by the nascent white middle classes whenever they faced popular demands in the space of the "European" city. ${ }^{57}$

\section{Final Words}

Which of the two accounts of the Chin-Yonk premiere was true, or at least the closest to reality? Did the journalists for La Nación and El Tiempo misunderstand that the applause was in jest, or did García Velloso lie? These questions naturally arise after reading the different accounts side by side. And while we might never know how events actually unfolded, what we can do is point out and interpret continuities and changes in the development of racial and social categories in Buenos Aires. Slippage between these two texts allows us to glimpse part of the process by which conceptions of modernity and progress, civilization and barbarism, became amalgamated with scientific theories of race and the formation of social class in Argentina. In so doing, we can begin to problematize a present-day Buenos Aires that is highly racialized, yet where race is hidden within divisions of class that are now seen as natural.

Similarly, these divergent accounts remind us how important it is to assess dominant or canonical texts in their historical contexts. Through García Velloso's piece, quoted and used countless time as an unquestionably true source, Zenón Rolón went from being an acclaimed composer and musician to an object of scorn. The playwright, having achieved enormous fame, did not hesitate to use his position to demolish the prestige still enjoyed by the maestro, hardwon in the face of ongoing processes of social erasure and forgetting. Rolón's transition from a modern gentleman to a negro was made possible by the account's irreproachability, whether because of the widespread conviction that there were no "real negros" in early twentieth-century Buenos Aires, or because no one remembered Rolón any longer, once the processes of Afro-Argentine

57. On the middle classes, see Ezequiel Adamovsky, Historia de la clase media argentina (Buenos Aires: Planeta, 2009); on the trope of “invasion," see Gastón Gordillo, “The Savage Outside of White Argentina," in Rethinking Race in Modern Argentina, ed. Paulina Alberto and Eduardo Elena (Cambridge and New York: Cambridge University Press, 2016), 241-267; and Alejandro Frigerio, “Luis D’Elía y los negros: Identificaciones raciales y de clase en sectores populares," Claroscuro 8 (2009): 13-43. 
erasure had taken place. Perhaps it was precisely this that had allowed García Velloso to write with complete brazenness and impunity, crafting such a patently racist account to which no one seemed to object.

García Velloso's account, so often cited or mentioned, so often referenced and remembered, thus embodies the historicity of memory itself-that is, the ways in which views of the past themselves change over time, not only according to a subject's own life experiences but also with the political, social, economic, and ideological transformations across that timespan. In this case, unfortunately, the passage of time also carried away all traces of dignity for an Afro-Argentine who had been greatly distinguished and admired in his own day, as it has for so many other Afro-Argentines, now forgotten. 